\title{
AKTA PENGIKATAN JUAL BELI TANAH SEBELUM DIBUATNYA AKTA PEJABAT PEMBUAT AKTA TANAH
}

\author{
Rifky Anggatiastara Cipta, Ngadino, Adya Paramita Prabandari \\ Program Studi Magister Kenotariatan \\ Fakultas Hukum, Universitas Diponegoro \\ Email : anggatiastara@gmail.com
}

\begin{abstract}
Land Purchase Binding Deed (PJB) of land cannot yet be used as a basis for land registration because it is still temporary before the buying and selling process is completed, because the registration requirements for the transfer of land rights are used by AJB PPAT. This study aims to determine the position of the PJB deed in the sale and purchase of land, its strengths and weaknesses. The method used is normative juridical. The results of the study showed that the PJB's position was an initial agreement before the AJB was made as a condition for the transfer of land rights in the certificate. In conclusion, the PJB Deed is not proof of the transfer of land rights. AJB must be made immediately after the PJB Deed is completed (paid off) as proof of the transfer of land rights. The power of the PJB deed is very strong because the PJB made before a notary is an authentic deed. Weaknesses of the PJB still need other legal action, namely the making of AJB as a condition for changing the ownership rights to the land due to buying and selling on certificates.
\end{abstract}

\section{Keywords: deed; binding of buying and selling land}

\begin{abstract}
Abstrak
Akta Pengikatan Jual Beli (PJB) tanah belum dapat digunakan dasar pendaftaran tanah karena masih bersifat sementara sebelum proses jual belinya selesai, karena syarat pendaftaran peralihan hak atas tanah digunakan AJB PPAT. Penelitian ini bertujuan mengetahui kedudukan akta PJB dalam jual beli tanah, kekuatan dan kelemahannya. Metode yang digunakan yuridis normatif. Hasil penelitian menunjukkan kedudukan PJB merupakan perjanjian awal sebelum dibuatnya AJB sebagai syarat peralihan hak atas tanah dalam sertipikat. Kesimpulannya Akta PJB bukan tanda bukti peralihan hak atas tanah. Agar segera dibuat AJB setelah Akta PJB selesai (lunas) sebagai bukti peralihan hak atas tanah. Kekuatan akta PJB yaitu sangat kuat karena PJB yang dibuat dihadapan notaris, merupakan akta otentik. Kelemahan PJB masih perlu tindakan hukum lain yaitu pembuatan AJB sebagai syarat perubahan hak milik atas tanah karena jual beli pada sertipikat.
\end{abstract}

Katakunci: akta; pengikatan jual beli tanah

\section{A. Pendahuluan}

Memperhatikan arti pentingnya pendaftaran peralihan hak atas tanah khususnya karena jual beli maka harus dilakukan sesuai dengan ketentuan peraturan hukum yang berlaku. Pengikatan jual beli harus jelas agar proses peralihan hak atas tanah dapat dilakukan di Kantor Pertanahan dibutuhkan Akta Jual beli sebagai bukti telah terjadinya perbuatan jual beli tanah.Namun pada kenyataannya ada jual beli tanah yang tidak dapat segera dibuatkan akta 
jual beli tanah oleh PPAT. Hal ini disebabkan karena proses jual beli memerlukan perbuatan hukum lain sebelum dilakukan pendaftaran peralihan hak atas tanah. Perbuatan hukum lain tersebut misalnya pemecahan bidang dalam hal jual beli tanah sebagian, penurunan hak atas tanah dalam hal:

a. Pemecahan tanah (penjualan sebagian bidang tanah)

b. Subyek hukum yaitu pihak calon pembeli tidak dalam kedudukan hukum untuk memiliki tanah milik atau tanah pertanian (absente)

c. Jual beli tanah yang pembayarannya belum lunas

d. Alasan lain sehingga pembuatan Akta Jual Beli belum dapat dilaksanakan.

e. Sertipikat hak milik dalam perusahaan.

Untuk menjamin kepastian hukum jual beli tanah yang masih memerlukan perbuatan hukum lain tersebut maka umumnya dilakukan pengikatan jual beli ke dalam sebuah akta. Hal ini agar masing-masing pihak mendapat perlindungan hukum atas jual beli tanah yang dilakukan. Akta pengikatan jual beli tanah tersebut belum dapat dijadikan sebagai dasar pendaftaran tanah karena pada dasarnya masih bersifat sementara sebelum tanah yang bersangkutan selesai proses jual belinya, karena syarat untuk dilakukan pendaftaran peralihan hak atas tanah dipergunakan Akta Jual Beli yang dibuat di hadapan Pejabat Pembuat Akta Tanah.

Pengikatan Jual Beli (PJB) tanah antara para pihak dapat dilakukan melalui akta di bawah tangan atau dapat pula dilakukan melalui suatu akta yang dibuat dihadapan notaris. Pengikatan jual beli tanah dengan status Sertipikat Hak Milik merupakan perbuatan hukum awal yang mendahului perbuatan hukum jual beli tanah. Notaris memiliki wewenang membuat akta pengikatan jual beli tanah dengan status Sertipikat Hak Milik (SHM) tapi tidak berwenang membuat akta otentik jual beli tanah bersertipikat hak milik (AJB), karena kewenangan membuat akta Jual Beli Tanah (AJB) bersertipikat Hak Milik ada pada PPAT (Patahna, 2009).

Mengenai hal ini sesuai dengan ketentuan Pasal 15 ayat (1) dan ayat (2) huruf f Undang-Undang Nomor 2 Tahun 2014 tentang Perubahan Atas Undang-Undang Nomor 30 Tahun 2004 tentang Jabatan Notaris yang menyatakan bahwa Notaris berwenang membuat Akta autentik mengenai semua perbuatan, perjanjian, dan penetapan yang diharuskan oleh peraturan perundang-undangan dan/atau yang dikehendaki oleh yang berkepentingan untuk dinyatakan dalam Akta autentik, menjamin kepastian tanggal pembuatan Akta, menyimpan Akta, memberikan grosse, salinan dan kutipan Akta, semuanya sepanjang pembuatan Akta itu tidak juga ditugaskan atau dikecualikan kepada pejabat lain atau orang lain yang ditetapkan 
oleh undang-undang. Selain kewenangan tersebut Notaris berwenang pula membuat Akta yang berkaitan dengan pertanahan.

Kemudian Pasal 2 ayat (1) dan ayat (2) huruf a Peraturan Pemerintah Nomor 37 Tahun 1998 tentang Peraturan Jabatan Pejabat Pembuat Akta Tanah disebutkan bahwa PPAT bertugas pokok melaksanakan sebagian kegiatan pendaftaran tanah dengan membuat akta sebagai bukti telah dilakukannya perbuatan hukum tertentu mengenai hak atas tanah atau Hak Milik Atas Satuan Rumah Susun, yang akan dijadikan dasar bagi pendaftaran perubahan data pendaftaran tanah yang diakibatkan oleh perbuatan hukum itu. Perbuatan hukum tersebut antara lain jual beli.

Praktiknya jual beli tanah menggunakan akta Pengikatan Jual Beli (PJB) terkadang mengalami kendala saat akan dilakukan pendaftaran peralihan hak atas tanah dengan Akta Jual Beli yang dibuat oleh PPAT. Kendala tersebut misalnya penjual meninggal dunia sehingga ahli waris tidak mau menandatangani Akta Jual Beli Tanah, atau pemilik tanah sendiri membatalkan jual beli tanah yang telah dibuat.

Satjipto Raharjo mengutip Fitzgerald menyatakan bahwa awal mula kemunculan teori perlindungan hukum bersumber dari teori hukum alam atau aliran hukum alam (Raharjo, 2000). Aliran hukum alam dipelopori Plato, Zeno (pendiri aliran Stoic) dan Aristoteles (murid Plato). Aliran hukum alam menyatakan bahwa hukum bersumber dari Tuhan yang mempunyai sifat global atau universal dan bersifat abadi, selain itu antara hukum dan moral tidak boleh ada pemisahan. Penganut aliran hukum alam memandang bahwa hukum dan moral merupakan representasi dan aturan yang secara internal maupun eksternal daripada kehidupan manusia merupakan perwujudan dari hukum dan moral (Patahna, 2009).

Perlindungan hukum pada prinsipnya merupakan perlindungan kepada subyek hukum yaitu orang dan/atau badan hukum ke dalam suatu bentuk perangkat baik yang bersifat prefentif atau bersifat represif, baik lisan atau tertulis. Perlindungan hukum merupakan upaya pemberian pengayoman terhadap hak asasi manusia yang dirugikan orang lain dan perlindungan tersebut diberikan kepada masyarakat agar masyarakat dapat menikmati hak-hak yang diberikan hukum atau dengan perkataan lain perlindungan hukum merupakan berbagai upaya hukum yang wajib diberikan aparat penegak hukum dalam rangka memberikan rasa aman, baik secara pikiran maupun fisik dari berbagai gangguan dan berbagai ancaman dari pihak manapun (Raharjo, 1993).

Perlindungan hukum adalah tindakan atau upaya untuk melindungi masyarakat dari perbuatan sewenang-wenang oleh penguasa yang tidak sesuai dengan aturan hukum, untuk 
mewujudkan ketertiban dan ketentraman sehingga memungkinkan manusia untuk menikmati martabatnya sebagai manusia (Setiono, 2004).

Konteks perlindungan hukum dalam artikel ini yaitu perlindungan hukum terhadap para pihak dalam akta pengikatan jual beli sebelum dibuat Akta Jual Beli oleh Pejabat Pembuat Akta Tanah. Para pihak dalam akta pengikatan jual beli mendapatkan perlindungan hukum dari kekuatan pembuktian akta. Namun akta pengikatan jual beli masih mempunyai kelemahan yaitu bukan sebagai bukti peralihak hak atas tanah karena jual beli sebagaimana AJB.

Berdasarkan latar belakang di atas, maka penulis membatasi fokus penelitian pada masalah mengenai kedudukan Akta PJB dalam proses jual beli tanah serta kekuatan dan kelemahan akta pengikatan jual beli dalam proses jual beli tanah sebelum dibuatnya akta jual beli oleh PPAT

Penelitian mengenai akta pengikatan jual beli tanah telah dilakukan beberapa peneliti. Namun penelitian ini mempunyai perbedaan mendasar terhadap penelitian yang telah ada. Adapun penelitian sebelumnya mengenai upaya hukum terhadap eksekusi benda jaminan antara lain:

a. Susanti (2008) dalam tesisnya meneliti mengenai "Praktek Perjanjian Pengikatan Jual Beli Hak Atas Tanah Berdasarkan Akta Notaris di Jakarta Timur”. Fokus penelitiannya pada kekuatan hukum Akta Perjanjian Pengikatan Jual Beli Hak Atas Tanah yang dibuat oleh Notaris dalam pelaksanaan pembuatan Akta Jual Belinya dan Kuasa Mutlak dalam Perjanjian Pengikatan Jual Beli serta status hukumnya dan perlindungan hukum terhadap pemenuhan hak-hak para pihak apabila salah satu pihak melakukan wanprestasi dalam perjanjian pengikatan jual beli (Susanti, 2008).

b. Laksita (2017) dalam jurnal melakukan penelitian "Legalitas Kuasa Dalam Akta Pengikatan Jual Beli Tanah Sebagai Dasar Pembuatan Akta Jual Beli (Studi di Kota Semarang)". Fokus penelitiannya legalitas kuasa dalam akta pengikatan jual beli tanah sebagai dasar pembuatan akta jual beli dan konsekuensi hukum terhadap penggunaan kuasa sebagai dasar pembuatan akta jual beli (Laksita, 2017).

\section{B. Metode Penelitian}

Penelitian ini merupakan penelitian yuridis normatif yaitu mengkaji dan menganalisa pokok permasalahan dalam obyek penelitian dengan mengkaitkan dengan norma-norma hukum yang berlaku. Berdasarkan hasil pembahasan selanjutnya dilakukan penarikan kesimpulan dan pemberian rekomendasi terhadap permasalahan yang ditemukan dalam obyek penelitian. 


\section{Hasil dan Pembahasan}

\section{Kedudukan Akta Pengikatan Jual Beli (PJB) dalam Proses Jual Beli Tanah}

Konsep dasar transaksi jual beli tanah adalah terang dan tunai. Terang, berarti dilakukan secara terbuka, jelas objek dan subjek pemilik, lengkap surat-surat serta bukti kepemilikannya. Tunai, berarti dibayar seketika dan sekaligus. Dibayarkan pajak-pajaknya, tanda tangan Akta Jual Beli, untuk kemudian diproses balik nama sertipikatnya.

Namun, pada praktiknya konsep terang dan tunai itu seringkali belum dapat dipenuhi. Belum terpenuhi, bukan berarti transaksi tidak bisa dilakukan, ada instrumen lain, yaitu dengan Akta Pengikatan Jual Beli ("PJB") sebagai pengikat, sebagai tanda jadi transaksi jual beli tersebut, sambil menunggu yang belum beres. Belum terpenuhinya persyaratan untuk Akta Jual Beli, bisa jadi karena pembayaran belum lunas/dicicil, sertipikat masih dalam proses pemecahan atau proses lainnya, belum mampu membayar pajak, atau kondisi lainnya yang legal.

Jika bentuknya adalah PJB Belum Lunas, maka di dalamnya tidak ada kuasa, kecuali syarat-syarat pemenuhan suatu kewajiban. Sedangkan jika pembayaran sudah lunas dan dibuatkan PJB Lunas, maka di dalamnya dibarengi dengan Kuasa untuk menjual, dari penjual kepada pembeli. Jadi, ketika semua persyaratan sudah terpenuhi, tanpa perlu kehadiran penjual-karena sudah terwakili-sudah memberikan kuasa, dengan redaksi kuasa untuk menjual kepada pembeli, Notaris/PPAT dapat langsung membuatkan Akta Jual Belinya untuk kemudian memproses balik nama sertifikatnya.

Pasal 1792 KUH Perdata ("KUHPerdata") menyebutkan, "Pemberian kuasa adalah suatu perjanjian dengan mana seorang memberikan kekuasaan kepada seorang lain, yang menerimanya, untuk atas namanya, menyelengarakan suatu urusan"

Menurut Patahna PJB tanah antara para pihak dapat dilakukan melalui akta di bawah tangan atau dapat pula dilakukan melalui suatu akta yang dibuat dihadapan notaris. Untuk tanah-tanah yang bersertipikat Hak Milik (SHM) maupun tanah yang belum memiliki Sertipikat Hak Milik (SHM) pengikatan jual belinya dapat dilakukan dihadapan notaris. Pengikatan jual beli tanah dengan status Sertipikat Hak Milik merupakan perbuatan hukum awal yang mendahului perbuatan hukum jual beli tanah. Notaris memiliki wewenang membuat akta pengikatan jual beli tanah dengan status Sertipikat Hak Milik (SHM) tapi tidak berwenang membuat akta otentik jual beli tanah bersertipikat hak milik (AJB), karena kewenangan membuat AJB bersertipikat Hak Milik ada pada PPAT. 
Pada prinsipnya suatu perjanjian PJB tunduk pada ketentuan umum perjanjian yang terdapat dalam Buku III KUH Perdata tentang Perikatan Pasal 1313 KUH Perdata memberikan rumusan tentang Perjanjian adalah "suatu perjanjian adalah suatu perbuatan dengan mana satu orang atau lebih mengikatkan dirinya terhadap satu orang atau lebih lainnya". Subekti memberikan definisi perjanjian adalah "Suatu peristiwa dimana seorang berjanji pada orang lain atau dimana dua orang itu saling berjanji untuk melaksanakan sesuatu hal.

Pasal 1338 ayat (1) KUH Perdata menyatakan bahwa, semua persetujuan yang dibuat secara sah berlaku sebagai undang-undang bagi mereka yang membuatnya. Pasal 1338 ini mengandung asas kebebasan berkontrak, maksudnya adalah setiap orang bebas mengadakan suatu perjanjian berupa apa saja, baik bentuknya, isinya, namanya dan pada siapa perjanjian itu ditujukan. Dari asas ini dapat disimpulkan bahwa masyarakat diperbolehkan membuat perjanjian yang berupa dan berisi apa saja (tentang apa saja) dan perjanjian itu mengikat mereka yang membuatnya seperti suatu undang-undang.

Namun dalam praktek sebelum dilakukannya jual beli tanah di hadapan PPAT yang berwenang, para pihak membuat akta pengikatan jual beli tanah di hadapan Notaris. Pengikatan dimaksudkan sebagai perjanjian pendahuluan dari maksud utama para pihak untuk melakukan peralihan hak atas tanah. Pengikatan jual beli ini memuat janji-janji untuk melakukan jual beli tanah apabila persyaratan yang diperlukan untuk itu telah terpenuhi (Supriadi, 2006).

Akta pengikatan jual beli tanah dalam prakteknya sering dibuat dalam bentuk akta otentik yang dibuat dihadapan Notaris, sehingga Akta Pengikatan Jual Beli merupakan akta otentik yang memiliki kekuatan pembuktian yang sempurna. Hal ini dimaksudkan oleh para pihak untuk lebih memberikan perlindungan dan kepastian hukum bagi para pihak yang membuatnya. Karena notaris dalam membuat akta tidak berpihak dan menjaga kepentingan para pihak secara obyektif. Dengan bantuan notaris para pihak yang membuat perjanjian pengikatan jual beli akan mendapatkan bantuan dalam merumuskan hal-hal yang akan diperjanjikan. Namun suatu perjanjian tidak selamanya dapat berjalan sesuai dengan kesepakatan yang diinginkan oleh para pihak.

Menurut Harijanto (2006:10) kondisi-kondisi tertentu dapat ditemukan terjadinya berbagai hal, yang berakibat suatu perjanjian mengalami pembatalan, baik dibatalkan oleh para pihak maupun atas perintah pengadilan (Harijanto, 2006).

Pengikatan Jual Beli (PJB) tanah antara para pihak dapat dilakukan melalui akta di bawah tangan atau dapat pula dilakukan melalui suatu akta yang dibuat dihadapan notaries. 
Untuk tanah-tanah yang bersertipikatHak Milik (SHM) maupun tanah yang belum memiliki Sertipikat Hak Milik (SHM) pengikatan jual belinya dapat dilakukan dihadapan notaris. Pengikatan jual beli tanah dengan status Sertipikat Hak Milik merupakan perbuatan hukum awal yang mendahului perbuatan hukum jual beli tanah. Jadi pengikatan jual beli berbeda dengan perbuatan hukum jual beli tanah. Notaris memiliki wewenang membuat akta pengikatan jual beli tanah dengan status Sertipikat Hak Milik (SHM) tapi tidak berwenang membuat akta otentik jual beli tanah bersertipikat hak milik (AJB), karena kewenangan membuat akta jual beli tanah (AJB) bersertipikat Hak Milik ada pada PPAT.

\section{Kekuatan dan kelemahan akta pengikatan jual beli dalam proses jual beli tanah sebelum dibuatnya akta jual beli oleh PPAT}

Perjanjian Pengikatan Jual Beli menurut R Subekti (1998) pengertiannya adalah perjanjian antar pihak penjual dan pihak pembeli sebelum dilaksanakannya jual beli dikarenakan adanya unsur-unsur yang harus dipenuhi terlebih dahulu untuk untuk dapat dilakukan jual beli antara lain adalah sertipikat belum ada karena masih dalam proses, belum terjadinya pelunasan harga. Sedang menurut Herlien Budiono, perjanjian pengikatan jual beli adalah perjanjian bantuan yang berfungsi sebagai perjanjian pendahuluan yang bentuknya bebas(Budiono, 2004).

Dari pengertian yang diterangkan di atas dapat dikatakan bahwa pengertian perjanjian pengikatan jual beli merupakan suatu perikatan bersyarat atau perjanjian pendahuluan yang dibuat sebelum dilaksanakannya perjanjian utama atau perjanjian pokoknya. Sebagaimana telah diterangkan tentang pengertiannya, maka kedudukan perjanjian pengikatan jual beli yang sebagai perjanjian pendahuluan maka perjanjian pengikatan jual beli berfungsi untuk mempersiapkan atau bahkan memperkuat perjanjian utama / pokok yang akan dilakukan, karena perjanjian pengikatan jual beli merupakan awal dari lahirnya perjanjian pokoknya yaitu Perjanjian Jual-Beli.

Perjanjian bantuan berfungsi dan mempunyai tujuan untuk mempersiapkan, menegaskan, memperkuat, mengatur, mengubah atau menyelesaikan suatu hubungan hukum. Dengan demikian jelas bahwa perjanjian pengikatan jual beli berfungsi sebagai perjanjian awal atau perjanjian pendahuluan yang memberikan penegasan untuk melakukan perjanjianpokoknya, serta menyelesaikan suatu hubungan hukum apabila hal-hal yang telah disepakati dalam perjanjian pengikatan jual beli telah dilaksanakan seutuhnya

Isi dari perjanjian pengikatan jual beli yang merupakan perjanjian pendahuluan untuk lahirnya perjanjian pokok/utama biasanya adalah berupa janji-janji dari para pihak yang 
mengandung ketentuan tentang syarat-syarat yang disepakati untuk sahnya melakukan perjanjian pokoknya. Misalnya dalam perjanjian pengikatan jual beli hak atas tanah, dalam klausul perjanjiannya biasanya berisi janjijanji baik dari pihak penjual hak atas tanah maupun pihak pembelinya tentang pemenuhan terhadap syarat-syarat agar perjanjian pokoknya yaitu perjanjian jual beli dan akta jual beli tersebut dapat ditanda tangani dihadapan PPAT, seperti janji untuk melakukan pengurusan sertipikat tanah sebelum jual beli dilakukan sebagaimana diminta pihak pembeli, atau janji untuk segera melakukan pembayaran oleh pembeli sebagai syarat dari penjual sebagai akta jual beli dapat ditandatangani dihadapan PPAT. Selain janji-janji biasanya dalam perjanjian pengikatan jual beli juga dicantumkan tentang hak memberikan kuasa kepada pihak pembeli.Hal ini terjadi apabila pihak penjual berhalangan untuk hadir dalam melakukan penandatanganan akta jual beli dihadapanPPAT, baik karena lokasi yang jauh, atau karena ada halangan dan sebagainya.Dan pemberian kuasa tersebut biasanya baru berlaku setelah semua syarat untuk melakukan jual beli hak atas tanah di PPAT telah terpenuhi(Patradi, 2010).

Menurut Sudarmanto, sebagai perjanjian yang lahir karena kebutuhan dan tidak diatur secara tegas dalam bentuk peraturan perundang-undangan maka perjanjian pengikatan jual beli tidak mempunyai bentuk tertentu(Sudarmanto, 2009).Hal ini sesuai juga dengan pendapat dari Herlien Budiono, perjanjian pengikatan jual beli adalah perjanjian bantuan yang berfungsi sebagai perjanjian pendahuluan yang bentuknya bebas. Akta perjanjian pengikatan jual beli yang dibuat dihadapan notaris adalah suatu perjanjian pengikatan jual beli atas objek tanah yang dibuat antara calon penjual dan calon pembeli yang dibuat sebelum ditandatanganinya Akta Jual Beli (AJB).Perjanjian pengikatan jual beli atas tanah yang bersertipikat hak milik dapat dilaksanakan dihadapan notaris sedangkan pembuatan akta jual beli wajib dilaksanakan dihadapanPPAT.Karena objek yang diperjualbelikan yakni tanah merupakan benda yang tidak bergerak akta jual beli tersebut pada umumnya perlu dilakukan pemenuhan sejumlah persyaratan baik oleh penjual maupun oleh pembeli.

Pemenuhan persyaratan dari pihak penjual pada umumnya berhubungan dengan suratsurat sebagai tanda bukti hak milik atas tanah tersebut maupun surat keterangan hak waris yang masih dalam pengurusan apabila tanah yang akan dijual tersebut merupakan harta warisan.

Reksomulyatno menyatakan, pelaksanaan jual beli dihadapan PPAT baru dapat dilaksanakan apabila pihak penjual telah melengkapi semua dokumen yang berhubungan dengan tanah tersebut untuk dapat dilangsungkannya perbuatan hukum jual beli.Akta perjanjian pengikatan jual beli dihadapan notaris dilakukan sebelum akta jual beli 
disebabkan karena adanya hambatan dari pihak pembeli(Reksomulyatno, 2010).Pada umumnya hambatan dari pembeli untuk terlaksanakannya akta jual beli tanpa harus melalui akta perjanjian pengikatan jual beli terlebih dahulu adalah kemampuan beli dari si pembeli tidak mencukupi untuk membeli secara tunai tanah tersebut. Oleh karena kemampuan/daya beli dari si pembeli tidak mencukupi untuk melakukan pembelian secara tunai maka dilaksanakanlah perjanjian pengikatan jual beli dihadapan notaris dimanadidalam perjanjian pengikatan jual beli tersebut disepakati dilaksanakan pembelian tanah tersebut dengan cara mencicil/mengangsur dalam jangka waktu tertentu (mingguan, bulanan) hingga harga penjualan tanah tersebut lunas dibayar oleh pembeli. Pada saat terjadinya pelunasan pembayaran harta tanah tersebut oleh pembeli maka pada saat itu dibuatlah akta jual beli dihadapan PPAT untuk dapat didaftarkan perubahan data kepemilikan haknya dikantor pertanahan tempat dimana tanah itu berada.Dengan demikian dapat dikatakan perjanjian pengikatan jual beli dapat pula terjadi berhubung karena pembelian atas tanah tersebut dilakukan berdasarkan angsuran/ cicilan yang telah disepakati oleh para pihak baik penjual maupun pembeli.

Menurut Gadiman, bahwa calon pembeli pada umumnya perlu melakukan cek bersih ke kantor pertanahan dimana tanah tersebut berada, sementara calon penjual perlu meminta uang muka (DP) sebagai tanda keseriusan pembelian tanah tersebut dari calon pembeli. Dalam rangka pemeriksaan ke kantor pertanahan dan pembayaran uang muka tersebut maka diperlukan adanya perjanjian pengikatan jual beli sebagai ikatan awal keseriusan para pihak untuk melakukan transaksi jual beli atas tanah tersebut (Gadiman, 2008).

PJB adalah perjanjian bantuan yang berfungsi sebagai perjanjian pendahuluan dan bentuknya bebas. Sebagaimana diketahui untuk terjadinya jual beli tanah hak dihadapanPPAT harus telah dilunasi harganya. Mungkin pula adanya keadaan dimana penjual yang sertipikat tanah haknya sedang dalam balik nama pada kantor Badan Pertanahan Nasional, akan tetapi penjual bermaksud untuk menjual hak tersebut. Guna mengatasi hal itu maka dibuatlah perjanjian pengikatan jual beli. Sebagai suatu perjanjian pendahuluan untuk sementara menantikan dipenuhinya syarat untuk perjanjian pokoknya yaitu jual beli dihadapanPPATyang berwenang membuatnya, maka biasanya di dalam perjanjian tersebut memuat janji-janji yang mengandung ketentuan-ketentuan mana kala syarat-syarat untuk jual beli di hadapan PPAT telah terpenuhi. Tentu saja para pihak setelah syarat untuk jual beli telah dipenuhi dapat datang lagi untuk melaksanakan jual beli dihadapanPPAT 
Akan tetapi adakalanya calon penjual berhalangan untuk datang kembali, dan pembeli untuk pelaksanaan penandatangan akta jual belinya bertindak sendiri baik mewakili penjual maupun dirinya sendiri selaku pembeli. Maka dalam hal ini diperlukan kuasa, selain kuasa tersebut biasanya penjual memberikan secara umum hak-hak kepengurusan (dadenvanbeheer) atas tanah hak tersebut selama belum dilakukan jual beli dihadapan pejabat yang dimaksud. Hal ini diperlukan mengingat, bahwa adanya kemungkinan penjual tidak berada ditempat untuk melakukan tindakan hukum yang masih merupakan kewajibannya tersebut. Untuk mengantisipasi keadaan itu maka notaris di dalam akta perjanjian pengikatan jual beli tersebut selalu mencantumkan kuasa-kuasa (blancovolmacht) di dalam aktanya dengan maksud agar pembeli tidak dirugikan haknya mengingat telah dipenuhi semua persyaratan untuk jual beli dihadapan pejabat yang berwenang PPAT. Dalam hal apabila seseorang ingin menjual sebidang tanah dan pihak yang satu lagi berkeinginan untuk membelinya maka mereka akan datang ke hadapan Pejabat Pembuat Akta Tanah, untuk dimintakan pembuatan akta jual beli atas tanah tersebut. Namun karena suatu sebab tertentu jual beli tersebut tidak dapat dilaksanakan, misalnya karena jual beli tersebut tidak lunas. Namun seandainya para pihak tersebut tetap berkeinginan untuk dimintakan pembuatan akta jual beli, untuk mengantisipasi hal itu PPAT yang juga berprofesi sebagai seorang Notaris akan menyarankan kepada para pihak untuk membuat akta persetujuan jual beli. Tujuan dari dibuatnya akta persetujuan jual beli tersebut salah satunya adalah agar pihak penjual dapat memperoleh sebagian atau seluruhnya dari harga jual beli tersebut dan pihak pembeli dapat memperoleh hak atas tanah tersebut walaupun secara riil belum terjadi (Jusran, 2009).

Faktor utama yang menyebabkan orang melakukan perjanjian pengikatanjual beli adalah karena jual beli itu belum lunas (secara cicilan) dan untuk menunda kewajiban membayar pajak, karena dengan melakukan transaksi perjanjian jual beli, pajak tidak akan timbul karena tidak ada pendaftaran peralihan hak sebagaimana yang diwajibkan di dalam peraturan mengenai Pejabat Pembuat Akta Tanah. Dengan kata lain dapat dikatakan hal itu untuk sementara menunda pelaksanaan pembayaran pajak. Dapat pula ditambahkan bahwa selain faktor-faktor tersebut diatas, adapun yang menyebabkan orang melakukan perjanjian perikatan jual beli adalah karena untuk melaksanakan jual beli langsung dihadapan Pejabat Pembuat Akta Tanah, maka kewajiban pembayaran pajak baik PPh maupun BPHTB harus telah dipenuhi, sedangkan untuk pembayaran pajak-pajak tersebut terutama BPHTB harus terlebih dahulu dilaksanakan verifikasi di Kantor Dinas Pendapatan Daerah apakah ada atau 
tidak tunggakan pembayaran PBB (Pajak Bumi dan Bangunan) atas obyek yang akan dijual belikan tersebut.

Pada prakteknya pemakaian Perjanjian Pengikatan Jual Beli sebagai perjanjian pendahuluan sudah sering digunakan untuk membantu dalam melakukan perjanjian jual-beli hak atas tanah, namun terhadap Perjanjian Pengikatan Jual Beli sendiri dalam penerapannya hanya memakai asas umum perjanjian yang diatur dalam KUH Perdata atau dengan kata lain belum ada diatur secara khusus dalam peraturan perundang-undangan yang berkaitan dengan hak atas tanah.

PJB merupakan sebuah terobosan hukum yang banyak dipakai oleh para pihak yang akan melakukan jual-beli hak atas tanah. PJB dipakai untuk memudahkan para pihak yang akan melakukan jual-beli hak atas tanah, karena jika mengikuti semua aturan yang diterapkan dalam melakukan jual-beli hak atas tanah, maka tidak semua dapat memenuhinya dalam sekali waktu, maksudnya tidak semua pihak mampu untuk langsung membayar semua persyaratan tentang jual-beli hak atas tanah dalam sekali waktu seperti membayar harga jual beli hak atas tanah yang dalam sekali waktu, seperti membayar harga jual beli hak atas tanah yang disepakati yang diikuti dengan pembayaran terhadap Pajak Penjual (SPP) dan Pajak Pembeli yaitu Bea Perolehan Hak Atas Tanah (BPHTB) serta kewajiban lain terkait dengan pembuatan dan pengurusan AJB serta perpindahan hak lainnya yaitu pendaftaran tanah (balik nama).

Peraturan tentang hak atas tanah, diantaranya adalah Undang-Undang Pokok Agraria (UUPA) Peraturan Pemerintah Nomor 40 Tahun 1996 tentang Hak Guna Usaha, Hak Guna Bangunan dan Hak Pakai Atas Tanah, Peraturan Menteri Negara Agraria Nomor 3 Tahun 1997 tentang ketentuan pelaksanaan Peraturan Pemerintah Nomor 24 Tahun 1997 dan lainlain, diatur secara tegas terhadap setiap perbuatan hukum yang berkaitan dengan hak atas tanah, maksudnya setiap orang yang akan melakukan perbuatan hukum yang berkaitan dengan hak atas tanah wajib tunduk kepada semua peraturan yang berkaitan dengan hak atas tanah. Misalnya dalam hal jual beli hak atas tanah, dimana dalam Peraturan Pemerintah Nomor 24 Tahun 1997 tentang Pendaftaran tanah dan Peraturan Pemerintah Nomor 37 Tahun 1998 tentang Peraturan Jabatan Pembuat Akta Tanah (PPAT), diatur bahwa dalam melakukan jual-beli hak atas tanah harus dilakukan dihadapan pejabat yang berwenang, dalam hal tanah adalah PPAT, yang daerah kerjanya meliputi daerah tempat tanah yang diperjualbelikan itu berada. Selain itu terhadap akta pemindahan haknya (akta jual belinya) juga dibuat oleh PPATdan akta jual beli tersebut merupakan akta otentik, dimana bentuk dan isinya telah ditentukan oleh peraturan perundangundangan yang berlaku. 
Sebelum melakukan jual-beli dihadapan pejabat yang berwenang, dalam hal tanah adalah PPAT dan dibuatkan akta jual belinya, para pihak yang akan melakukan jual beli hak atas tanah harus memenuhi semua persyaratan yang diatur dalam pelaksanaan jual beli tanah. Misalnya Persyaratan tentang objek jual belinya, seperti hak atas tanah yang akan diperjualbelikan merupakan hak atas tanah yang sah dimiliki oleh penjual yang dibuktikan dengan adanya sertipikat tanah atau tanda bukti sah lainnya tentang hak tersebut, dan tanah yang diperjualbelikan tidak berada dalam sengketa dengan pihak lain dan sebagainya.

Persyaratan lainnya misalnya jual-beli yang telah disepakati dan akan dibuatkan aktanya telah dibayar secara lunas terhadap harga atas tanahnya beserta semua pajak yang berkaitan dengan jual-beli hak atas tanah seperti pajak penghasilan dari penjual(SSP) dan pajak pembeli yaitu (Bea Perolehan Hak Atas Tanah dan Bangunan /BPHTB) telah dilunasi oleh pihak yang akan melakukan jual-beli(Ramdan, 2010).

Dari semua pengertian yang dikemukakan di atas maka dapat disimpulkan bahwa pengertian Akta Pengikatan Jual Beli menurut pendapat peneliti adalah surat yang ditandatangani antara penjual dan pembeli dalam jual-beli hak atas tanah sebelum dilaksanakannya jual beli yang sebenarnya dikarenakan adanya unsur-unsur yang harus dipenuhi untuk jual beli yang berfungsi sebagai Perikatan bersyarat yang bentuknya bebas. Sebagai perjanjian yang tidak diatur secara tegas atau khusus oleh peraturan perundangundangan yang berlaku, maka perlu kita ketahui tentang kedudukan dan kekuatan dari Pengikatan Jual Beli itu sendiri.Berbicara tentang kekuatan hukum yang dimiliki oleh Pengikatan Jual-Beli, maka kita hars mengkaji tentang Perjanjian Pengikatan Jual-Beli secara lebih mendalam.

Pengikatan jual beli dapat berlaku dalam dua kedudukan tergantung bagaimana perjanjian PJB itu dibuat. Pengertian dari akta otentik diterangkan dalam Pasal 1868 KUH Perdata yang berbunyi :"Suatu Akta Otentik ialah suatu akta yang di dalam bentuk yang ditentukan oleh Undang-undang di buat oleh atau dihadapan pegawai-pegawai umum yang berkuasa untuk itu ditempatdimana akta dibuatnya”. Berdasarkan Pasal 1868 KUH Perdata tersebut di atas dapatlah dilihat bahwa untuk akta otentik bentuk dari aktanya ditentukan oleh Undang-undang dan harus dibuat oleh atau dihadapan Pegawai yang berwenang. Pegawai yang berwenang yang dimaksud disini antara lain adalah Notaris, hal ini didasarkan pada ketentuan Pasal 1 angka 1 Undang-Undang Nomor 1 Tahun 2004 tentang Jabatan Notaris yang menyatakan bahwa Notaris adalah Pejabat Umum yang berwenang untuk membuat akta otentik dan berwenang lainnya sebagai dimaksud dalam Undang-undang ini. Jadi sesuai yang aturan dalam Pasal 1868 KUH Perdata ditetapkan atau dapat dikatakan 
bahwa syarat untuk akta otentik adalah sebagai berikut : a. Akta itu harus dibuat "oleh" (door) atau "dihadapan" (tenoverstaan) seorang pejabat umum;b. Akta itu harus dibuat dalam bentuk yang ditentukan Undang-undang; c. Pejabat umum oleh atau dihadapan siapa aka itu dibuat, harus mempunyai wewenang untuk membuat akta itu.

Keterangan di atas terlihat bahwa pada Pengikatan Jual Beli (PJB), yang dibuat dihadapan atau oleh Notaris maka akta perjanjian Pengikatan Jual Beli (PJB) menjadi sebuah akta yang otentik. Karena telah dibuat dihadapan atau oleh pejabat yang berwenang (salah satunya Notaris) sehingga telah memenuhi ketentuan atau syarat tentang akta otentik yaitu harus dibuat "oleh" (door) atau "dihadapan" (tenoverstaan) seorang pejabat umum. Pengikatan jual beli tidak dibuat dihadapan pejabat umum maka Pengikatan Jual Beli (PJB) menjadi akta di bawah tangan, dan untuk Akta dibawah tangan lebih lanjut diatur dalam Pasal 1874 KUH Perdata yang menyatakan bahwa sebagai tulisan-tulisan di bawah tangan dianggap akta-akta yang ditanda tangani di bawah tangan, surat-surat, register-register, surat-surat urusan rumah tangga dan lainlain, tulisan yang dibuat tanpa perantara seorang pegawai umum (Mertokusumo, 2004).

Penandatanganan sepucuk tulisan di bawah tangan dipersamakan suatu cap jempol, dibubuhi dengan suatu pernyataan yang tertinggal dari seorang Notaris atau pegawai lain yang ditunjuk oleh Undang-Undang dari mana ternyata bahwa ia mengenal si pembubuh cap jempol, atau bahwa orang ini telah diperkenalkan kepadanya, bahwa isinya akta telah diperjelaskan kepada orang itu, dan bahwa setelah itu cap jempol tersebut dibubuhkan dihadapan pegawai tadi. Pegawai ini harus membukukan tulisan tersebut.Dengan Undangundang dapat diadakan aturan-aturan lebih lanjut tentang pernyataan dan pembukuan termaksud.

Berdasarkan semua keterangan yang telah dikemukakan di atas maka dapat disimpulkan bahwa kekuatan hukum dari akta perjanjian pengikatan jual beli hak atas tanah yang dibuat oleh Notaris dalam pelaksanaan pembuatan Akta Jual Belinya adalah sangat kuat. Hal ini karena Pengikatan Jual Beli (PJB) yang dibuat dihadapan notaris, maka aktanya telah menjadi akta notaril sehingga merupakan akta otentik, sedangkan untuk yang dibuat tidak di hadapan notaris maka menjadi akta di bawah tangan yang pembuktiannya berada dibawah akta otentik, walaupun dalam Pasal 1875 KUH Perdata memang disebutkan bahwa akta dibawah tangan dapat mempunyai pembuktian yang sempurna seperti akta otentik apabila tanda tangan dalam akta tersebut diakui oleh para pihak yang menanda tanganinya. 
Namun ketentuan dalam Pasal 1875 KUH Perdata menunjuk kembali 1871 KUH Perdata yang menyatakan bahwa akta di bawah tangan dapatlah menjadi seperti akta otentik namun tidak memberikan bukti yang sempurna tentang apa yang termuat di dalamnya, karena akan dianggap sebagai penuturan belaka selain sekedar apa yang dituturkan itu ada hubungan langsung dengan pokok isi akta.

Kelemahan akta pengikatan jual beli dalam proses jual beli tanah sebelum dibuatnya akta jual beli oleh PPAT yaitu akta pengikatan jual beli bukan merupakan bukti pengalihan hak atas atas. Akta Pengikatan Jual Beli untuk peralihan hak atas tanah masih diperlukan tindakan hukum lain yaitu pembuatan Akta Jual Beli sebagai alat bukti peralihan hak atas tanah sebagai syarat perubahan hak milik atas tanah karena jual beli tanah pada sertipikat.

Jadi ketentuan hukum yang ada di perjanjian pengikatan jual-beli hanyalah tergantung dimana perjanjian pengikatan jual-beli dibuat, jika bukan dihadapan pejabat umum (notaris) maka menjadi akta dibawah tangan sedangkan jika dibuat oleh atau dihadapan pejabat umum maka akta tersebut menjadi akta notariil yang bersifat akta otentik.

\section{Simpulan}

Kedudukan Akta PJB dalam proses jual beli tanah merupakan perjanjian awal sebelum dibuatnya AJB sebagai syarat peralihan hak atas tanah dalam sertipikat. Akta PJB bukan merupakan tanda bukti peralihan hak atas tanah. Berdasarkan hal tersebut maka dalam perjanjian jual beli tanah agar segera dilakukan pembuatan AJB sesaat setelah Akta Pengikatan Jual Beli selesai (lunas) sebagai bukti peralihan hak atas tanah. Selain itu pembuatan akta pengikatan jual beli harus dilakukan dengan itikad baik dan terbuka agar jual beli dapat dilaksanakan dengan lancar

Kekuatan akta pengikatan jual beli dalam proses jual beli tanah sebelum dibuatnya akta jual beli oleh PPAT adalah sangat kuat. Hal ini karena PJB yang dibuat di hadapan notaris, maka aktanya telah menjadi akta notaril sehingga merupakan akta otentik. Akta pengikatan jual beli bukan merupakan bukti pengalihan hak atas atas. Kelemahannya masih diperlukan tindakan hukum lain yaitu pembuatan Akta Jual Beli sebagai alat bukti peralihan hak atas tanah sebagai syarat perubahan hak milik atas tanah karena jual beli tanah pada sertipikat. 


\section{DAFTAR PUSTAKA}

\section{Buku :}

Gadiman,D.(2008).Hak Dan Kewajiban Para Pihak Dalam Perjanjian Pengikatan Jual Beli Tanah Bersertipikat. Bandung: Sumber Ilmu.

Jusran, H.(2009). Hukum Perjanjian Innominaat Dalam Praktek. Jakarta: Citra Media Ilmu.

Mertokusumo,S.(1998)Hukum Acara Perdata Indonesia.ed. V. cet.I. Yogyakarta : Liberty.

Patahna, M. (2009).Problematika Notaris. Jakarta: Rajawali.

Patradi, K.(2010).Pemberian Kuasa Dalam Praktek Perjanjian Pengikatan Jual Beli Hak Atas Tanah. Yogyakarta: Gamma Press.

Raharjo, S.(2000). Ilmu Hukum. Bandung: Citra Aditya Bakti.

Ramdan, H.(2010).Kewajiban-Kewajiban Dalam Pelaksanaan Jual Beli Tanah Bersertifikat. Jakarta: Pustaka Ilmu.

Reksomulyatno, D.(2010).Perjanjian Pengikatan Jual-Beli Sebagai PerjanjianInnominaat. Jakarta: Bina Ilmu.

Subekti, R.(1998). Hukum Perjanjian. Jakarta: Penerbit Intermasa.

Sudarnanto, A. (2009). Pejabat Pembuat Akta Tanah, Antara Kewenangan Dan Kewajiban. Semarang: Pelita Ilmu.

Supriadi. (2006).Etika dan Tanggung Jawab Profesi Hukum di Indonesia. Jakarta: Sinar Grafika.

\section{Artikel Jurnal / Karya Ilmiah}

Budiono, H. (2004). Pengikatan Jual Beli dan Kuasa Mutlak. Majalah Renvoi, Ed. tahun I,(No.10, Maret).

Laksita, S.D. (2017).Legalitas Kuasa Dalam Akta Pengikatan Jual Beli Tanah Sebagai Dasar Pembuatan Akta Jual Beli (Studi di Kota Semarang),Diponegoro Law Journal, Vol.6,(No. 1).

Mertokusumo, S.(2004). Arti Penemuan Hukum. Majalah Renvoi, Ed. tahun I,(No.12, Mei).

Rahardjo, S. (1993). Penyelenggaraan Keadilan Dalam Masyarakat Yang Sedang Berubah. Jurnal Masalah Hukum.

Susanti, F. (2008). Praktek Perjanjian Pengikatan Jual Beli Hak Atas Tanah Berdasarkan Akta Notaris di Jakarta Timur. Universitas Diponegoro.

\section{Undang-undang dan Peraturan}

Undang-Undang Nomor 5 Tahun 1960 tentang Peraturan Dasar Pokok-Pokok Agraria.

KUH Perdata 
Peraturan PemerintahNomor 24 Tahun 1997 tentangPendaftaran Tanah

Peraturan Pemerintah Nomor 37 Tahun 1998 tentang Peraturan Jabatan Pembuat Akta Tanah (PPAT)

Peraturan Menteri Negara Agraria/Kepala Badan Pertanahan Nasional Nomor 3 Tahun 1997 tentang Ketentuan Pelaksanaan Peraturan Pemerintah Nomor 24 Tahun 1997 Tentang Pendaftaran Tanah. 